\title{
Characterization of steel billet scales generated during the continuous casting process in SIDERPERU steel plant
}

\author{
L. E. Borja-Castro ${ }^{1}$ - A. Bustamante Dominguez ${ }^{1}$ - M. I. Valerio-Cuadros ${ }^{1,2}$. \\ R. A. Valencia-Bedregal ${ }^{1}$ - H. A. Cabrera-Tinoco ${ }^{1,3}$ - S. M. Espinoza Suarez ${ }^{1} \cdot$ J. Kargin ${ }^{4}$. \\ N. O. Moreno ${ }^{5}$. C. H. W. Barnes ${ }^{6} \cdot$ L. De Los Santos Valladares ${ }^{1,4,6}$
}

Accepted: 21 November 2021 / Published online: 6 December 2021

(C) The Author(s) 2021

\begin{abstract}
Tons of waste is produced during iron steel's industrial production, creating environmental pollution. This work aims to characterize the steel scale formed on the billet surface during the last step of steel production in the SIDERPERU steel plant. Scanning Electron Microscopy (SEM) shows stacked layers one above the other on steel billets scales surface. Energy Dispersive X-ray (EDX) and X-ray Fluorescence (XRF) reveal the high content of $\mathrm{Fe}$ and $\mathrm{O}$, with $\mathrm{Ca}, \mathrm{Si}, \mathrm{Mn}$, and $\mathrm{Cr}$ as minority elemental compounds. X-ray Diffraction (XRD) shows $\mathrm{FeO}, \alpha-\mathrm{Fe}_{2} \mathrm{O}_{3}$ and $\mathrm{Fe}_{3} \mathrm{O}_{4}$ as crystallographic phases. Magnetometry reveals Verwey transition and paramagnetic signals that screen the Morin transition. Mössbauer Spectroscopy at room temperature displays magnetic and non-magnetic parts. The nonmagnetic part has the hyperfine parameters corresponding to predominant nonstoichiometric wustite. Octahedral $\left(\mathrm{Fe}^{+2} / \mathrm{Fe}^{3+}\right)$ and tetrahedral $\mathrm{Fe}^{+3}$ hyperfine fields of 46.0 and $49.4 \mathrm{~T}$ values respectively are associated to nonstoichiometric magnetite and another sextet with a hyperfine field of $52.0 \mathrm{~T}$ is related to hematite.
\end{abstract}

Keywords Steel billet scale $\cdot$ Continuous casting $\cdot$ Iron oxides $\cdot$ Mössbauer spectroscopy

\section{Introduction}

Steel production generates a tremendous amount of waste, which is no longer utilized stored in dumps for decades and creates pollution to the environment. Therefore, it is not strange that the steel industry contributes to $\mathrm{CO}_{2}$ emissions [1]. The steel waste generated

This article is part of the Topical Collection on Proceedings of the International Conference on the Applications of the Mössbauer Effect (ICAME 2021), Brasov, Romania, 5-10 September 2021 Edited by Victor Kuncser

L. E. Borja-Castro

luis.borja@unmsm.edu.pe

L. De Los Santos Valladares

1d301@cam.ac.uk

Extended author information available on the last page of the article 
can be classified as carbon steel and stainless-steel slag depending on the steel products, and according to the steelmaking process as Electric Arc Furnace (EAF) slag, Ladle Furnance (LF) slag and continuous casting residue (Mill Scales) [2]. There are attempts to recycle EAF and LF slag and utilize them in some sectors, such as for roads, pavements and bricks [3]. Mill scales are the metallurgical waste generated by oxidation process on the surface of the metal during the hot rolling process in the steelmaking industry $[4,5]$. Annually, more than 13.5 million tons of mill scale waste are generated around the globe [6], which is treated as waste by the steel industry [4], despite of its high content of Fe and iron oxides minerals composition [7]. SIDERPERU is one of the main leading steel companies in Perú. Its capacity production exceeds the 500 kton of steel finished and by-products. Every $40 \mathrm{~min}$, this steel plant generates a particular batch of a certain batch liquid steel containing iron compounds, calcium and magnesium oxides. In one day of production 90 tons of slag is produced and no longer reused. So, it is crucial to recycle it or to reuse it in other industries to reduce their environmental impact. Kargin et al. has developed and reported a cost-efficient method of processing metallurgical rolling mill scales waste to produces hematite and maghemite nanopowders [8]. In this context, we aim is to characterize the mill scales, known as billet scales, formed during the continuous casting process of steelmaking in the SIDERPERU steel plant and report their content of iron-mineral for later recycling.

\section{Experimental details}

In SiderPeru, steel is obtained via 'secondary production', i.e. by recycling steel scrap in an electric arc furnace (EAF) between 3000 and $5000{ }^{\circ} \mathrm{C}$. The reduction process of the ironcompounds is performed at $1600-1700{ }^{\circ} \mathrm{C}$ in a ladle furnace. The liquid steel is then chemically equilibrated only be composed of iron, carbon and some chemical elements such as $\mathrm{Mn}$ and $\mathrm{Si}$ in minimum concentration. The transformation into billets is made by pouring this liquid into moulds with a sectional square. Each face of this mould is cooled down with water to solidify the liquid steel. Then the cut is made to specific lengths. Throughout reaction with water and air, white spots are formed on the surfaces of the billets which grow until the so-called steel billet scales are formed. These steel billet scales were collected and characterized. The morphology of the samples was inspected through a scanning electron microscope (SEM) Philips XL-30, with a resolution of $10 \mathrm{~nm}$ at $30 \mathrm{kV}$, Voltage range: $0.5 \mathrm{~V}$ to $30 \mathrm{kV}$ and magnification of $300,000 \times$ adapted with an EDX-OXFORD Xplorer spectrometer for the semiquantitative elemental analysis. An X-ray fluorescence XRF-720 Shimadzu spectrometer was also used to detect and register the elemental composition, which counts with an advantage algorithm that allows the analysis of a variety of types of matrices.

The X-ray diffraction (XRD) measurements were performed on Rigaku Brand diffractometers using both, cobalt $\left(\mathrm{Co} \lambda_{\mathrm{K} \alpha}=1.79026 \AA\right)$ and copper $\left(\mathrm{Cu} \lambda_{\mathrm{K} \alpha}=1.54056 \AA\right)$ radiations, in the same geometry conditions. These measures were carried out in order to identify the crystallographic phases present in the sample and to improve the detection of iron oxides detected by copper radiation. The magnetic measurements were carried out using a DC-MPMS-SQUID magnetometer (Quantum Design Inc.) in zero-field cooling (ZFC) and field cooling (FC) modes. The magnetization as a function of temperature was collected from 5 to $400 \mathrm{~K}$ and applying an external magnetic field of $500 \mathrm{Oe}$ and $10 \mathrm{kOe}$. The applied field dependence of the magnetization was also measured in the range $\pm 10 \mathrm{kOe}$ 
and at 5300 and $400 \mathrm{~K}$. The Mössbauer measurement was carried out at room temperature using a Mössbauer spectrometer in transmission geometry. A radioactive source of 57Co (Rh) of $50 \mathrm{mCi}$ of nominal activity was employed with a transducer in constant acceleration with data acquisition in 1024 channels platform. For standard calibration $\alpha$-Fe foil piece was used and fitting with Lorentzian profiles using the WinNormos software acquired by the laboratory.

\section{Results and discussion}

Figure 1a) shows a photography taken during the continuous casting of the billets on whose surface scales grow. Figure 1b) shows billets scales formed. They consist of dark gray plate pieces, with smooth surfaces and very brittle to touch by hands. The SEM Micrography with the topography surface and colored map are indicated in Figs. 1c) and d), respectively where it is observed that the scales surface is formed by stackings layers and agglomerated particles of about $100 \mu \mathrm{m}$ diameters. EDX and XRF spectra in Fig. 1e) and f) show Fe and $\mathrm{Ca}$ as common chemical elements. Table 1 lists the elemental composition of the steel billet scales sample. Fe is the main chemical element detected by EDX and XRF techniques. $\mathrm{O}$ is the secondary chemical element detected by EDX technique, while $\mathrm{Si}, \mathrm{Mn}, \mathrm{Ca}$ and $\mathrm{Co}$ are the minimal elements registered by the same technique. $\mathrm{Mn}, \mathrm{Cr}$ and $\mathrm{Cu}$ detected by $\mathrm{XRF}$ also in minimal concentration. The difference in the elemental composition provided by both techniques is mainly related to the difference between penetration depth than inhomogeneity of the sample. To note, XRF penetrates the sample deeper than EDX, allowing the former technique to detect more elements than the second one [9].

Figure 2 shows the obtained result for X-ray Diffraction for steel billet scales. A cobalt target was also used in the measurements to avoid the fluorescence effect by copper radiation in iron oxide components resulting in lower diffraction intensity. For steel billet scale sample, the resultant diffractograms in cobalt and copper radiation are differentiated by their intensity and shape profile, as we can observe for reflections for (111), (200) and (220); (220), (311), (400) and (400); (012), (104), (110), (113), (024), (116) and (300) display in Fig. 2a). The main crystalline phases identified are wüstite (FeO, PDF card No. 01-073-2145). Magnetite ( $\mathrm{Fe}_{3} \mathrm{O}_{4}$, PDF card No. 01-073-2145) is detected as secondary phase, whereas hematite $\left(\alpha-\mathrm{Fe}_{2} \mathrm{O}_{3}\right.$. PDF card No. 00-033-0664) appears as minor phase. These components come from the oxidation of iron in contact with water and air during the cooling process of the steel billets. In other words, the oxidation process occurs due to the reaction of Fe with $\mathrm{O}$ to form wustite on the surface of the billets. Some proportion of this wustite oxidizes to magnetite and, eventually, as the cooling process reaches the room temperature to hematite [10]. Its related parameters are listed in Table 2. These results obtained by XRD are similar to the reported by Bagatini et al. in their studies on mill scale and Farahat et al. in their work in the reduction of mill scale [11, 12]. Note that the mineral phases are in well agree to compositional elements found by EDX and XRF. Also, in Fig. 2a) and b) we can see a broad peak labeled by in the red square that can be associated with the presence of some iron silicates or carbonate silicates as shown in the EDX and FRX techniques.

Figure 3(a) shows the magnetization as a function of temperature curves of billet scales measured under applied magnetic fields of $500 \mathrm{Oe}$ and $10 \mathrm{kOe}$. The $\mathrm{M}(\mathrm{T})$ curves show a reduction of irreversibility in $\mathrm{ZFC}$ and $\mathrm{FC}$ over the entire range of temperature as the external field increases from 500 Oe to $10 \mathrm{kOe}$. This reduction is due to the alignment of 

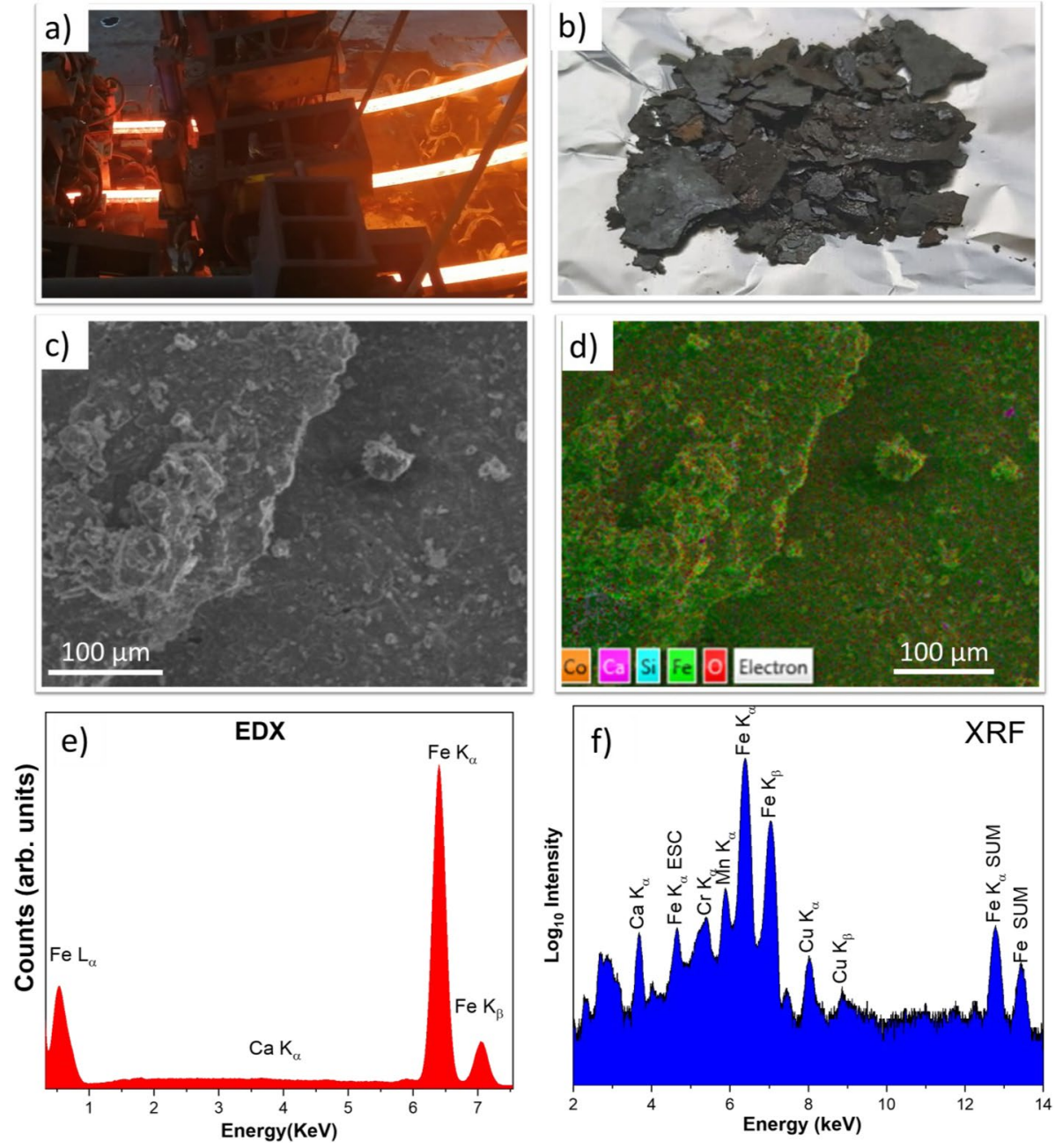

Fig. 1 a A photography taken during continuous casting of steel billets where scales are formed, b a photography of the scales, $\mathbf{c}$ and $\mathbf{d}$ SEM micrograph of scales surface, e EDX and $\mathbf{f}$ XRF spectra

Table 1 Elemental composition for steel billet scale sample

\begin{tabular}{llllllll}
\hline EDX & & & & & \\
\hline Element & $\mathrm{Fe}$ & $\mathrm{O}$ & $\mathrm{Mn}$ & $\mathrm{Co}$ & $\mathrm{Cu}$ & $\mathrm{Si}$ & $\mathrm{Ca}$ \\
\hline Wt\% & $72.8(1)$ & $25.2(3)$ & $0.78(1)$ & $0.43(2)$ & $0.39(1)$ & $0.25(2)$ & $0.12(1)$ \\
XRF & & & & & & \\
Element & $\mathrm{Fe}$ & - & $\mathrm{Mn}$ & - & $\mathrm{Cu}$ & - & $\mathrm{Ca}$ \\
Mass \% & $97.92(1)$ & - & $1.014(1)$ & - & $0.454(1)$ & - & $0.373(2)$ \\
\hline
\end{tabular}



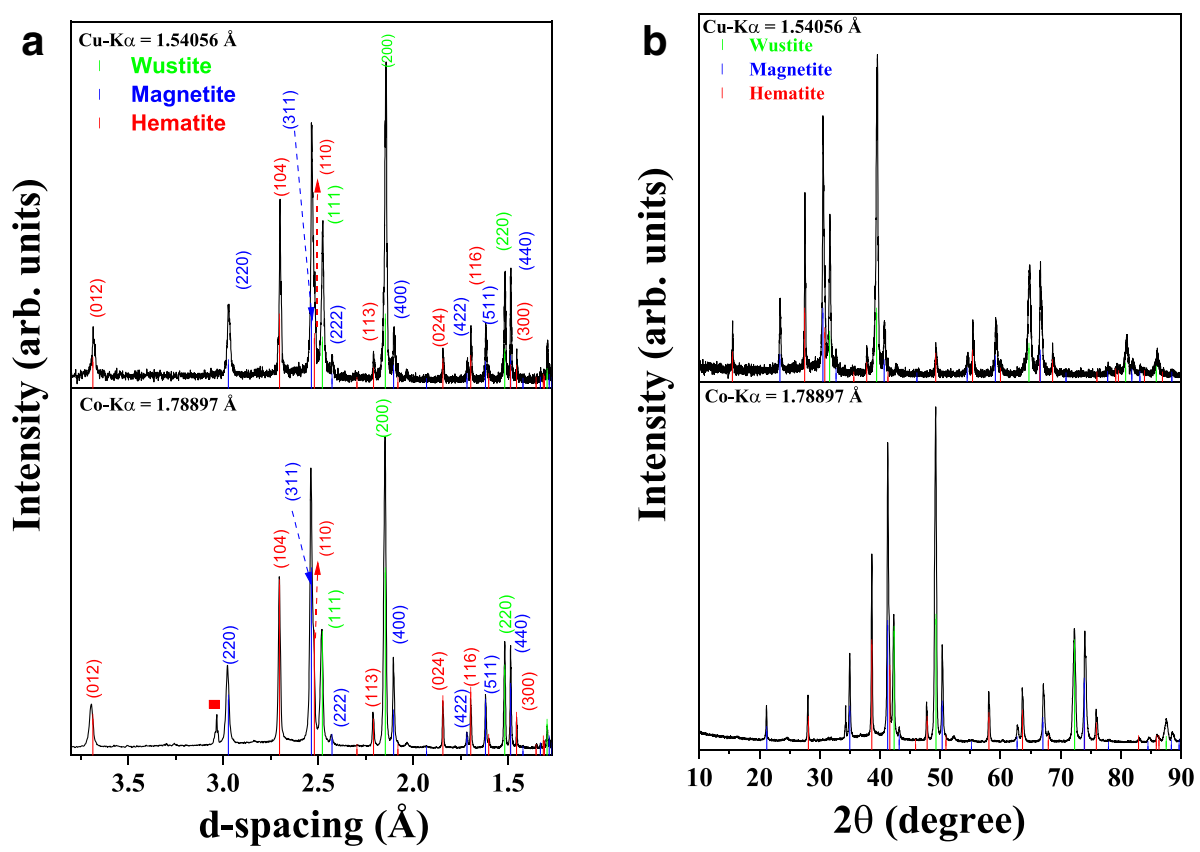

Fig. 2 XRD of steel billet scales collected from SIDERPERU steel plant a intensity vs interplanar distance and $\mathbf{b}$ intensity vs $2 \theta$

ferromagnetic domains to the external field resulting in magnetization gain. Verwey transition [13] is registered at $\mathrm{T} \sim 120 \mathrm{~K}$ when the applied magnetic field is 500 Oe confirming the presence of magnetite detected by XRD. Note that also hematite and wustite were detected by XRD. However, the Morin transition from hematite at 250-260 K [14] and the antiferromagnetic-to-paramagnetic transition of wustite at 200-210 K are not revealed in the $\mathrm{M}(\mathrm{T})$ curves. These transitions must be screened by the ferrimagnetic signal of magnetite and signals from other magnetic elements. In this way, under higher applied magnetic fields, such as $10 \mathrm{kOe}$ (blue curve in the figure), most of the domains in the sample align ferromagnetically in the whole range of temperature.

Figure 3(b) displays the external field dependence of the magnetization $\mathrm{M}(\mathrm{H})$ at 5, 150, 300 and $400 \mathrm{~K} . \mathrm{M}(\mathrm{H})$ reveals narrow hysteretic behaviors of soft ferromagnetic materials. From the $\mathrm{M}-\mathrm{H}$ plots it can be observed that the steel billet scales almost saturated above $9 \mathrm{kOe}$ for all temperatures demonstrating the ferromagnetic alignment. The Mr./Ms. rates values and coercive field tend to decrease with increasing the temperature due to the competition between the thermal and magnetic energy of magnetic domains, as mentioned above. Note that the ratio of Mr./Ms. is by far less than 1, so the bill scale tends to behave more paramagnetic than ferromagnetic.

Figure 4 shows the Mossbauer spectrum taken at room temperature for the scales sample. The hyperfine parameters are listed in Table 3. The spectra are composed of nonmagnetic and magnetic parts. Three Zeeman sextets and two paramagnetic doublets were used to fit the spectra. Two doublets in the fitted spectra correspond to nonstoichiometric wustite $\left(\mathrm{Fe}_{1-\mathrm{x}} \mathrm{O}\right)$. One doublet is present with $\delta_{\mathrm{Fe}}=0.9 \mathrm{~mm} / \mathrm{s}$ and $\Delta \mathrm{E}_{\mathrm{Q}}=0.73 \mathrm{~mm} / \mathrm{s}$ due to the electronic exchange between $\mathrm{Fe}^{2+}$ and $\mathrm{Fe}^{3+}$ in the octahedral site. Another doublet with $\delta_{\mathrm{Fe}}=0.38 \mathrm{~mm} / \mathrm{s}$ and $\Delta \mathrm{E}_{\mathrm{Q}}=0.60 \mathrm{~mm} / \mathrm{s}$ is attributed to the electronic exchange between 
Table 2 Mineralogical phases, relative percentage abundance, cell parameters, Miller indexes, peak positions and crystallite sizes obtained from the XRD analysis of steel billet scale samples

\begin{tabular}{|c|c|c|c|c|c|}
\hline Phase & $\%$ & Cell parameters & $\begin{array}{l}\text { Miller Index } \\
(h k l)\end{array}$ & $2 \theta\left({ }^{\circ}\right)$ & $\begin{array}{l}\text { Crystal- } \\
\text { lite size } \\
(\mathrm{nm})\end{array}$ \\
\hline \multirow[t]{4}{*}{ Wustite } & \multirow[t]{4}{*}{38.8} & \multirow{4}{*}{$\begin{array}{l}\mathrm{a}=\mathrm{b}=\mathrm{c}=4.288(1) \AA \\
\alpha=\beta=\gamma=90.0 \\
\text { Space: Fm-3 m }\end{array}$} & 111 & 42.3 & 56 \\
\hline & & & 200 & 49.2 & 32 \\
\hline & & & 220 & 72.2 & 23 \\
\hline & & & 311 & 87.5 & 22 \\
\hline \multirow[t]{10}{*}{ Magnetite } & \multirow[t]{10}{*}{36.1} & \multirow{10}{*}{$\begin{array}{l}\mathrm{a}=\mathrm{b}=\mathrm{c}=8.395(3) \AA \\
\alpha=\beta=\gamma=90.0 \\
\text { Space: } \mathrm{Fd}-3 \mathrm{~m}\end{array}$} & 111 & 21.1 & 56 \\
\hline & & & 220 & 34.9 & 43 \\
\hline & & & 311 & 41.2 & 43 \\
\hline & & & 222 & 43.1 & 28 \\
\hline & & & 400 & 50.4 & 40 \\
\hline & & & 422 & 62.8 & 27 \\
\hline & & & 333 & 67.2 & 28 \\
\hline & & & 440 & 74.0 & 28 \\
\hline & & & 620 & 84.7 & 27 \\
\hline & & & 533 & 88.6 & 24 \\
\hline \multirow[t]{10}{*}{ Hematite } & \multirow[t]{10}{*}{25.0} & \multirow{10}{*}{$\begin{array}{l}\mathrm{a}=\mathrm{b}=5.033(3) \AA . \\
\mathrm{c}=13.753(4) \AA . \\
\alpha=\beta=90.0 \\
\gamma=120.0 \\
\text { Space: } \mathrm{R}-3 \mathrm{c}\end{array}$} & 012 & 28.0 & 52 \\
\hline & & & 104 & 38.6 & 49 \\
\hline & & & 110 & 41.5 & 40 \\
\hline & & & 113 & 47.8 & 43 \\
\hline & & & 024 & 58.1 & 39 \\
\hline & & & 116 & 63.7 & 35 \\
\hline & & & 300 & 75.9 & 32 \\
\hline & & & 208 & 84.7 & 27 \\
\hline & & & 1010 & 85.9 & 59 \\
\hline & & & 119 & 86.2 & 23 \\
\hline
\end{tabular}

$\mathbf{a}$

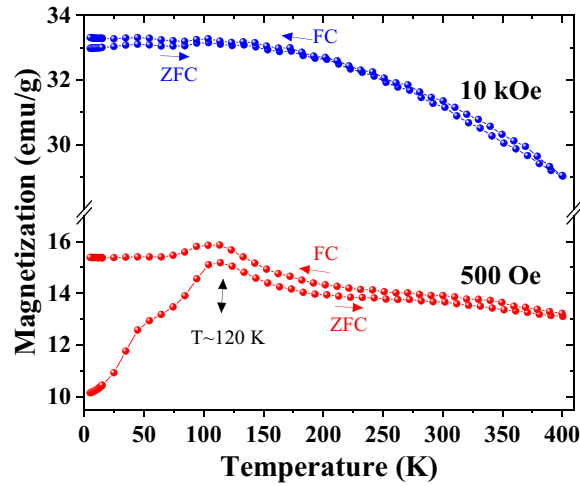

b

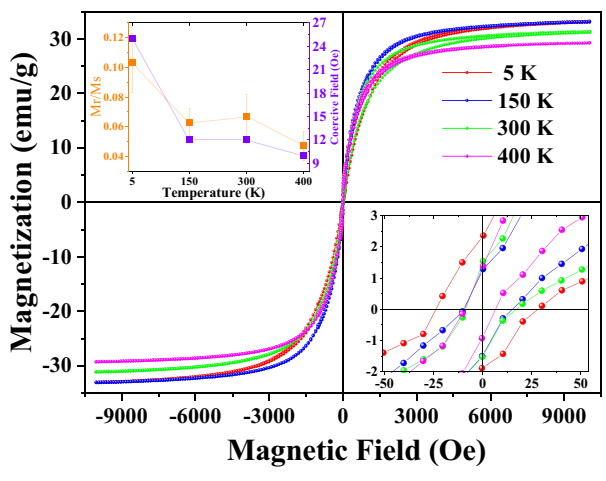

Fig. 3 Magnetic responses of steel billet scales collected from SIDERPERU a M(T) at 500 and 10 KOe and b $\mathrm{M}(\mathrm{H}), \mathrm{Mr} . / \mathrm{Ms}$. rate and coercive fields as insets 
Fig. 4 Mössbauer spectrum of billet scales sample from SIDERPERU steel plant taken at RT

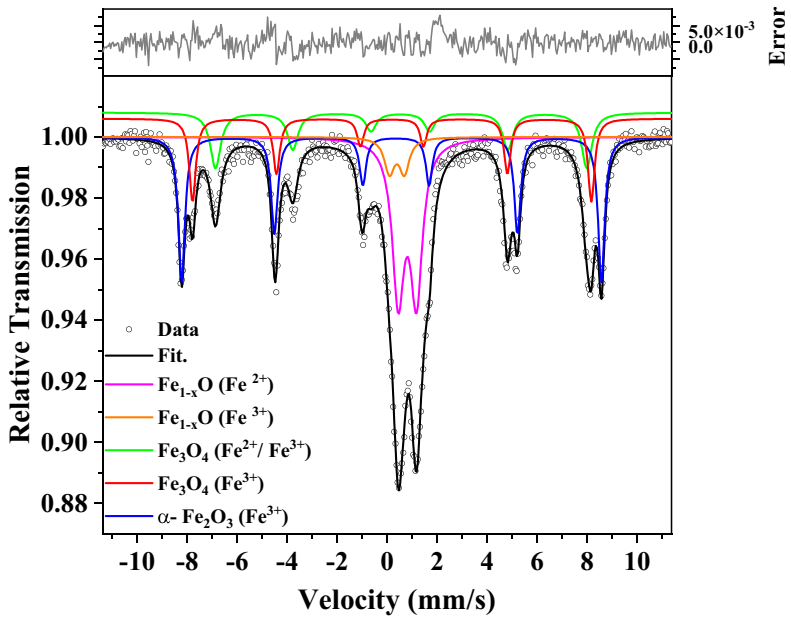

Table 3 Hyperfine parameters values for steel billet scales at room temperature were obtained from Mössbauer spectra fitting. $\delta_{\mathrm{Fe}}$ : Isomer shift relative to $\alpha$-Fe at room temperature, $\Delta \mathrm{E}_{\mathrm{Q}}$ : quadrupole splitting, $2 \varepsilon$ : quadrupole splitting, $\mathrm{B}_{\mathrm{hf}}=$ hyperfine magnetic field, $\mathrm{W}$ : line width and RAA: relative absorption area

\begin{tabular}{llllll}
\hline Subspectra & $\delta_{\mathrm{Fe}}(\mathrm{mm} / \mathrm{s})$ & $\Delta \mathrm{E}_{\mathrm{Q}} / 2 \varepsilon(\mathrm{mm} / \mathrm{s})$ & $\mathrm{B}_{\mathrm{hf}}(\mathrm{T})$ & $\mathrm{W}(\mathrm{mm} / \mathrm{s})$ & RAA $(\%)$ \\
\hline *Wustite $\left(\mathrm{Fe}^{2+}\right)$ & $0.9(2)$ & $0.73(1)$ & - & $0.57(1)$ & 38.9 \\
*Wustite $\left(\mathrm{Fe}^{3+}\right)$ & $0.38(3)$ & $0.60(2)$ & - & $0.42(2)$ & 6.1 \\
Magnetite $\left(\mathrm{Fe}^{2+} / \mathrm{Fe}^{3+}\right)$ & $0.65(2)$ & $0.03(2)$ & $46.0(2)$ & $0.5(2)$ & 20.8 \\
Magnetite & $0.30(2)$ & & $49.4(3)$ & 0.32 & 12.8 \\
$\left(\mathrm{Fe}^{3+}\right)$ & $0.36(2)$ & $-0.17(4)$ & $52.0(2)$ & $0.31(4)$ & 21.4 \\
Hematite & & & & \\
\hline
\end{tabular}

*non-stoichiometric wustite

tetrahedral $\mathrm{Fe}^{3+}$ and octahedral $\mathrm{Fe}^{2+}$ sites. This result is consistent with the literature [15, 16]. The relative absorption area (RAA) given by the two doublets of wustite accounts for $45 \%$ which is in higher proportion. Such results agree with the XRD results suggesting wustite as the main crystallographic phase. Two Zeeman sextets with hyperfine magnetic field $\mathrm{B}_{\mathrm{hf}}=46.0$ and $49.4 \mathrm{~T}$ are typical for magnetite in octahedral $\left(\mathrm{Fe}^{2+} / \mathrm{Fe}^{3+}\right)$ and tetrahedral $\left(\mathrm{Fe}^{3+}\right)$ sites $[17,18]$, see Table 3. The ratio between the RAA octahedral and tetrahedral sites accounts to 1.63 which is smaller than 1.8 for pure magnetite. This means that the magnetite present in steel billets scales is nonstoichiometric maybe due to the partial substitutions at Fe Sites for the elements registered by EDX and XRF techniques above. Magnetite RAA accounts for $33.6 \%$, thus it is in the intermediate fraction. According to the previous XRD results, the hyperfine magnetic field $\mathrm{B}_{\mathrm{hf}}=52 \mathrm{~T}$ is related to weakly ferromagnetic hematite $[19,20]$ according to XRD results above.

The relative absorption area obtained from the fitting process of the Mössbauer spectra provides an estimation of the relative abundance of the iron oxide components in the sample. Thus, according to Table 3, wustite in their oxidation states of $\mathrm{Fe}^{2+}$ and $\mathrm{Fe}^{3+}$ accounts for an RAA $45.0 \%$. The tetrahedral $\left(\mathrm{Fe}^{3+}\right)$ and octahedral $\left(\mathrm{Fe}^{2+} / \mathrm{Fe}^{3+}\right)$ sites of magnetite give a total RAA of $33.6 \%$ and hematite an RAA of $21.4 \%$. These values tell us that most 
abundant iron oxide in the sample is wustite, followed by magnetite and hematite. These results agree well agreement with the obtained values by XRD above (see Table 2).

\section{Conclusions}

Steel billet scales generated during the continuous casting process in SIDERPERU plant were characterized. They have plates in the micrometer scale, that are dark gray in color and very brittle. EDX and XRF found that $\mathrm{Fe}$ and $\mathrm{O}$ are the main chemical elemental composition. $\mathrm{Ca}, \mathrm{Si}, \mathrm{Mn}, \mathrm{Co}, \mathrm{Cr}$ were recorded, but in minimal concentration. Wustite $(\mathrm{FeO})$, magnetite $\left(\mathrm{Fe}_{3} \mathrm{O}_{4}\right)$ and hematite $\left(\alpha-\mathrm{Fe}_{2} \mathrm{O}_{3}\right)$ were found by XRD technique as the main crystallographic phases. Verwey transition signal was detected in the temperature dependent magnetization (M-T) curves at an applied magnetic field of 500 Oe. Above the Verwey temperature the diamagnetic signal of the non-magnetic components screens the Morin transition related to hematite. At $10 \mathrm{kOe}$ a ferromagnetic signal was detected due to the increase of the magnetization values and loss of the ZFC and FC irreversibility. Mössbauer spectroscopy confirms the presence of iron oxides such as wustite, magnetite and hematite. According to the presented results, wustite is the predominant component, magnetite is the intermediate and hematite is the minor one. Mössbauer spectroscopy also has revealed that the wustite and magnetite are non-stoichiometric.

Acknowledgements This work was supported by the CONCYTEC - World Bank - FONDECYT program "Incorporación de Investigadores", Contract No. 12 -2019 - FONDECYT - BM - INC. INV. The authors are indebted to Mr. E. Hurtado Aguilar and Mr. R.H Cervantes Altuna for allowing the access to SiderPerú to collect the samples.

Open Access This article is licensed under a Creative Commons Attribution 4.0 International License, which permits use, sharing, adaptation, distribution and reproduction in any medium or format, as long as you give appropriate credit to the original author(s) and the source, provide a link to the Creative Commons licence, and indicate if changes were made. The images or other third party material in this article are included in the article's Creative Commons licence, unless indicated otherwise in a credit line to the material. If material is not included in the article's Creative Commons licence and your intended use is not permitted by statutory regulation or exceeds the permitted use, you will need to obtain permission directly from the copyright holder. To view a copy of this licence, visit http://creativecommons.org/licenses/by/4.0/.

\section{References}

1. Pauliuk, S., Milford, R.L., Müller, D.B., Allwood, J.M.: Supplementary information - the steel scrap age. Environ. Sci. Technol. 47, 3448-3454 (2013)

2. Yi, H., Xu, G., Cheng, H., Wang, J., Wan, Y., Chen, H.: An overview of utilization of steel slag. Procedia Environ. Sci. 16, 791-801 (2012). https://doi.org/10.1016/j.proenv.2012.10.108

3. Prim, S.R., Folgueras, M.V., de Lima, M.A., Hotza, D.: Synthesis and characterization of hematite pigment obtained from a steel waste industry. J. Hazard. Mater. 192, 1307-1313 (2011). https://doi.org/ 10.1016/j.jhazmat.2011.06.034

4. Jikar, P.C., Dhokey, N.B.: Overview on production of reduced iron powder from mill scale waste. Mater. Today Proc. 44, 4324-4329 (2020). https://doi.org/10.1016/j.matpr.2020.10.552

5. Ruhiyuddin, M.Z., Murizam, D., Ahmad, K.R.: Synthesis and characterization of iron produced from iron mill scale. Key Eng. Mater. 594-595, 118-122 (2014). https://doi.org/10.4028/www.scientific.net/ KEM.594-595.118

6. Cho, S., Lee, J.: Metal recovery from stainless steel mill scale by microwave heating. Met. Mater. Int. 14, 193-196 (2008). https://doi.org/10.3365/met.mat.2008.04.193 
7. Cunha, A.F. da, Mol, M.P.G., Martins, M.E., Assis, P.S.: Caracterização, beneficiamento e reciclagem de carepas geradas em processos siderúrgicos. Rem Rev. Esc. Minas. 59, 111-116 (2006). https://doi. org/10.1590/s0370-44672006000100014

8. Kargin, D.B., Konyukhov, Y.V., Biseken, A.B., Lileev, A.S., Karpenkov, D.Y.: Structure, morphology and magnetic properties of hematite and Maghemite Nanopowders produced from rolling mill scale. Steel Transl. 50, 151-158 (2020). https://doi.org/10.3103/S0967091220030055

9. Chauhan, A.: Deformation and damage mechanisms of ODS steels under high-temperature cyclic loading. Int. J. Fatigue. 93, 1-17 (2018)

10. Marciuš, M., Ristić, M., Ivanda, M., Musić, S.: Formation of iron oxides by surface oxidation of iron plate. Croat. Chem. Acta. 85, 117-122 (2012). https://doi.org/10.5562/cca1943

11. Farahat, R., Eissa, M., Megahed, G.: Reduction of Mill Scale Generated by Steelprocessing. J. Steel Relat. Mater. (2010)

12. Bagatini, M.C., Zymla, V., Osório, E., Vilela, A.C.F.: Characterization and reduction behavior of mill scale. ISIJ Int. 51, 1072-1079 (2011). https://doi.org/10.2355/isijinternational.51.1072

13. Walz, F.: The Verwey transition - a topical review. J. Phys. Condens. Matter. 14, (2002). https://doi. org/10.1088/0953-8984/14/12/203

14. Özdemir, Ö., Dunlop, D.J., Berquó, T.S.: Morin transition in hematite: size dependence and thermal hysteresis. Geochemistry, Geophys. Geosystems. 9, (2008). https://doi.org/10.1029/2008GC002110

15. Gheisari, M., Mozafari, M., Niyaifar, M., Amighian, J., Soleimani, R.: Observation of small exchange bias in defect wüstite (Fe 0.93O) nanoparticles. J. Supercond. Nov. Magn. 26, 237-242 (2013). https:// doi.org/10.1007/s10948-012-1821-9

16. Benard, J.: The oxidation of metals and alloys. Metall. Rev. 9, 473-503 (1964). https://doi.org/10. 1179/mtlr.1964.9.1.473

17. Doriguetto, A.C., Fernandes, N.G., Persiano, A.I.C., Nunes Filho, E., Grenèche, J.M., Fabris, J.D.: Characterization of a natural magnetite. Phys. Chem. Miner. 30, 249-255 (2003). https://doi.org/10. 1007/s00269-003-0310-x

18. Vandenberghe, R.E., De Grave, E.: Application of Mössbauer spectroscopy in earth sciences. Mössbauer Spectrosc. 91-185, (2013). https://doi.org/10.1007/978-3-642-32220-4_3

19. Gaviría, J.P., Bohé, A., Pasquevich, A., Pasquevich, D.M.: Hematite to magnetite reduction monitored by Mössbauer spectroscopy and X-ray diffraction. Phys. B Condens. Matter. 389, 198-201 (2007). https://doi.org/10.1016/j.physb.2006.07.056

20. Stevens, J.G., Khasanov, A.M., Miller, J.. W., Pollack, H., Li, Z.: Mössbauer Mineral Handbook. Mössbauer Effect Data Center, The University of North Carolina at Asheville 206 Rhoades Hall (2006)

Publisher's note Springer Nature remains neutral with regard to jurisdictional claims in published maps and institutional affiliations.

\section{Authors and Affiliations}

\section{E. Borja-Castro' ${ }^{1}$ A. Bustamante Dominguez ${ }^{1}$ M. I. Valerio-Cuadros ${ }^{1,2}$.}

R. A. Valencia-Bedregal ${ }^{1}$ • H. A. Cabrera-Tinoco ${ }^{1,3}$ - S. M. Espinoza Suarez ${ }^{1}$ • J. Kargin ${ }^{4}$. N. O. Moreno ${ }^{5}$. C. H. W. Barnes ${ }^{6} \cdot$ L. De Los Santos Valladares ${ }^{1,4,6}$

1 Laboratorio de Cerámicos y Nanomateriales, Facultad de Ciencias Físicas, Universidad Nacional Mayor de San Marcos, Ap. Postal 14-0149, Lima, Peru

2 Departamento de Física, Universidade Estadual de Maringá, Av. Colombo, 5790 - Jardim Universitário, Maringá, PR 87020-900, Brazil

3 Facultad de Ingeniería, Universidad Continental, 15311 Lima, Peru

4 Department of Technologies Commercialization, L. N. Gumilyov Eurasian National University, Astana 010000, Kazakhstan

5 Departamento de Física, Universidade Federal de Sergipe, São Cristóvão, SE 49100-000, Brazil

6 Cavendish Laboratory, Department of Physics, University of Cambridge, J.J Thomson Av., Cambridge CB03 OH3, UK 